\title{
THE USE OF SPONTANEOUS CONTINUOUS POSITIVE AIRWAY PRESSURE (CPAP) FOR REDUCTION OF INTRAPULMONARY SHUNTING IN ADULTS WITH ACUTE RESPIRATORY FAILURE
}

\author{
Govind P. Garg ${ }^{\circ}$ and Gary E. Hill
}

ThE value of using positive end-expiratory pressure (PEEP) in conjunction with continuous mechanical ventilation has been well established. It has been shown that, in the majority of cases, PEEP added during continuous ventilation increases arterial $\mathrm{P}_{\mathrm{O}_{2}}$ and decreases the alveolar-arterial oxygen tension gradient $\left(A-a D_{O_{2}}(1.0)\right) \uparrow$, while inspired oxygen percentage remains the same. ${ }^{1-5}$. Therefore, adding PEEP during continuous ventilation allows the physician to lower the higher potentially toxic concentration of inspired oxygen $\left(\mathrm{F}_{\mathrm{I}_{2}}\right)$ necessary to maintain an adequate arterial blood $\mathrm{P}_{\mathrm{O}_{2}}$.

Use of continuous spontaneous positive airway pressure (CPAP) breathing in the treatment of idiopathic respiratory distress syndrome in infants has recently been popularized by Gregory, et al. ${ }^{6}$ Civetta and others ${ }^{7}$ recently described the use of CPAP in adult patients with acute respiratory failure. Pontoppidan and others ${ }^{8,8}$ have reported some results with CPAP in similar situations.

Guidelines for selecting patients to be treated with CPAP therapy are lacking in the literature.

The purpose of this paper is to illustrate the details of our actual mechanical set-up for CPAP modified for adult patients, to report our experience and findings with this form of therapy, and briefly to discuss the indications and guidelines for the use of CPAP in adults with respiratory failure.

\section{Matertals And Methods}

The mechanical assembly used in these studies is shown in the illustration (Figure 1).

All patients were in acute respiratory failure, and all were on intermittent positive pressure ventilation (IPPV) prior to the initiation of spontaneous CPAP therapy. Vital capacity and tidal volume were measured with a Wright respirometer connected to the tracheal tube or tracheostomy. In one unconscious patient, it was not possible to measure the vital capacity and therefore an inspiratory force

From Department of Anesthesiology and Respiratory Therapy, Vanderbilt University School of Medicine, Nashville, Tennessee.

- Present address: Department of Anaesthesiology, University of Texas Health Science Center at San Antonio, 7703 Floyd Curl Drive, San Antonio, Texas 78284.

$\mid \mathrm{A}-\mathrm{aD}_{\mathrm{O}_{2}}(1.0)=$ Alveolar-arterial oxygen tension during 100 per cent oxygen breathing: $A-\mathrm{aD}_{\mathrm{O}_{2}}(1.0)=\mathrm{PA}_{\mathrm{O}_{2}}-\mathrm{PaO}_{2}, \mathrm{PA}_{\mathrm{O}_{2}}=\mathrm{PB}-\left(\mathrm{P}_{\mathrm{H}_{2} \mathrm{O}}+\mathbf{P}_{\mathrm{CO}_{2}}\right) . \mathrm{PAO}_{\mathrm{A}_{2}}=$ Alveolar oxygen tension. $\mathrm{Pa}_{\mathrm{O}_{2}}=$ Arterial oxygen tension. $\mathrm{F}_{\mathrm{O}_{2}}=$ Fraction of inspired oxygen concentration, i.e., $\mathrm{F}_{\mathrm{O}_{2}}=$ 100 per cent oxygen. 


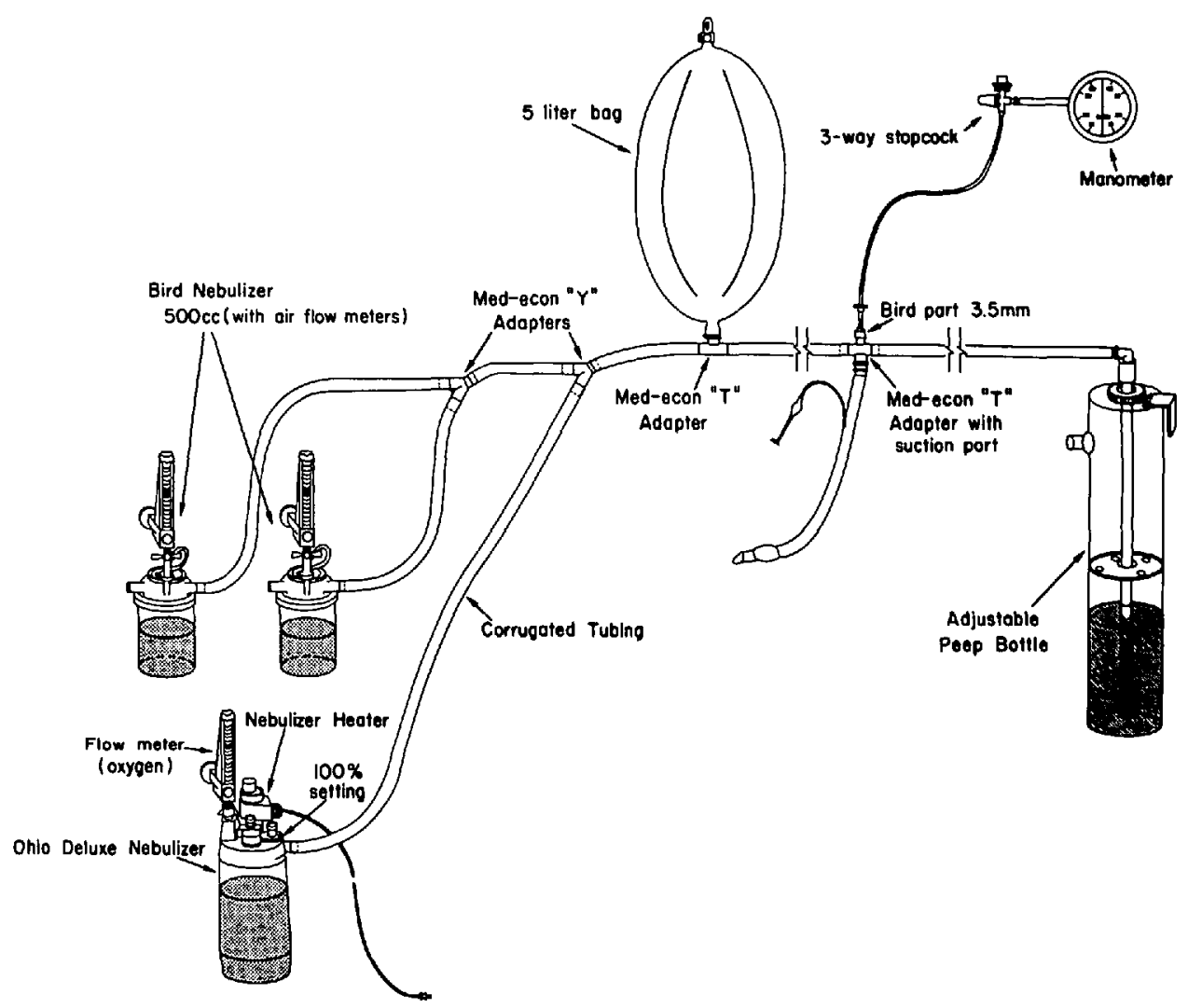

Figure 1. Adult CPAP Set-Up: Two room-temperature nebulizers with air flow-meters and one heated nebulizer with oxygen flow-meter are connected to a 5-liter anaesthesia reservoir bag and a bottle made from plexiglass. It has wide bore calibrated tubing, which dips under water. To achieve a desired amount of positive end-expiratory pressure with spontaneous breathing, the calibrated wide bore tubing must be immersed to the desired level of the underwater column first, and then connected to the system with the reservoir bag. Total gas flow must be in the range of $2 \frac{1}{2}$ to 3 times the minute volume of the patient ( 20 to 30 liters). The underwater column is kept constant and the total flow is adjusted until the bag remains distended and the desired CPAP is achieved. The oxygen saturation can be verified by an analyzer connected to the 3-way stop cock.

meter (spring gauge meter measured in $\mathrm{cms} \mathrm{H}_{2} \mathrm{O}$, normal for adults 25 to $150 \mathrm{cms}$ $\mathrm{H}_{2} \mathrm{O}$ ) was used to measure the inspiratory force. None of these patients had a previous history of respiratory failure.

Before initiation of CPAP, arterial blood sampling was performed after the patient was on 100 per cent oxygen for 20 minutes or more while on a mechanical ventilator (IPPV). The oxygen concentration was confirmed by a Beckman analyzer inserted into the inspiratory limb of the respirator. Oxygen and carbon dioxide tensions and $\mathrm{pH}$ of the blood samples were determined without delay on a Corning Model \#165 blood gas analyzer. Barometric pressure was read from a standard barometer. Alveolar-arterial oxygen tension difference in 100 per cent oxygen $\left(\mathrm{A}-\mathrm{aD}_{\mathrm{O}_{2}}\right)$ was calculated $\left(\mathrm{PAO}_{\mathrm{O}_{2}}-\mathrm{Pa}_{\mathrm{O}_{2}}=\mathrm{A}-\mathrm{aD}_{\mathrm{O}_{2}}{ }^{(1.0)}\right)$.

After CPAP therapy was instituted, patients were monitored for blood pressure by standard blood pressure cuffs, pulse rate and respiratory rate changes were re- 
TABLE I

\begin{tabular}{|c|c|c|c|c|c|c|c|c|}
\hline Patient & Age/Sex & Weight & Diagnosis & $\begin{array}{l}\text { Days } \\
\text { IPPV } \\
\text { Before } \\
\text { CPAP }\end{array}$ & $\begin{array}{l}\text { Days } \\
\text { CPAP }\end{array}$ & $\begin{array}{l}\text { Avg cm } \\
\text { of } \\
\text { CPAP }\end{array}$ & $\begin{array}{c}\text { Avg. } \\
\text { A-aDo: } \\
\text { Before } \\
\text { CPAP }\end{array}$ & $\begin{array}{l}\text { After } \\
\text { CPAP }\end{array}$ \\
\hline$\# 3$ & $57 / \mathrm{M}$ & 235 & $\begin{array}{l}\text { Atelectasis } \\
\text { pneumonia }\end{array}$ & 3 & 2 & 10 & 375 & 313 \\
\hline$\# 4$ & $68 / \mathrm{M}$ & 190 & Atelectasis & 2 & 4 & 7 & 440 & 333 \\
\hline$\# 5$ & $63 / \mathrm{M}$ & 185 & $\begin{array}{l}\text { Chronic } \\
\text { bronchitis } \\
\text { "Shock lung" }\end{array}$ & 2 & 2 & 5 & 416 & 370 \\
\hline$\# 6$ & $48 / \mathrm{M}$ & 160 & $\begin{array}{l}\text { Aspiration } \\
\text { pneumonia }\end{array}$ & 2 & 21 & 7.5 & 436 & 341 \\
\hline$\# 7$ & $73 / \mathrm{M}$ & 155 & $\begin{array}{l}\text { Atelectasis } \\
\text { chronic } \\
\text { bronchitis }\end{array}$ & 1 & 2 & 5 & 400 & 359 \\
\hline$\# 8$ & $44 / \mathrm{M}$ & 165 & "Shock lung" & 5 & 2 & 6 & 555 & 376 \\
\hline$\# 9$ & $63 / \mathrm{M}$ & 185 & $\begin{array}{l}\text { Atelectasis } \\
\text { pneumonia }\end{array}$ & 2 & 2 & 5 & 378 & 307 \\
\hline$\# 10$ & $72 / \mathrm{M}$ & 195 & $\begin{array}{l}\text { Pulmonary } \\
\text { oedema }\end{array}$ & 1 & 16 & 8 & 564 & 389 \\
\hline Average & 61 & 184 & & 2.3 & 6.4 & 7.1 & 445 & 348.5 \\
\hline
\end{tabular}

corded every 5 to 10 minutes. The starting $\mathrm{F}_{\mathrm{IO}_{2}}$ was usually 0.4 . Arterial samples were drawn after approximately 15 minutes to rule out carbon dioxide retention. When patients had maintained a normal or near normal arterial $\mathrm{P}_{\mathrm{CO}_{2}}$, they were placed on 100 per cent oxygen with CPAP by turning off one air mixing flow nebulizer and adding an Ohio Deluxe Nebulizer in series with the oxygen flowmeter, with additional oxygen flows of 15 to 20 liters per minute into the system. Blood samples were again drawn at the end of 20 minutes of breathing 100 per cent oxygen and $\mathrm{A}-\mathrm{aD}_{\mathrm{O}_{2}}{ }^{(1.0)}$ was calculated as described.

\section{Results}

All patients in this series except No. 1 and No. 8 (Table I) were conscious, alert and uncomfortable on the respirator prior to CPAP therapy. All conscious patients had vital capacity greater than 12 to $15 \mathrm{cc} / \mathrm{kg}$ and tidal volumes greater than 4 to 6 $\mathrm{cc} / \mathrm{kg}$. In the two unconscious patients (No. 1 and No. 8), the inspiratory force was greater than $25 \mathrm{~cm} \mathrm{H}_{2} \mathrm{O}$ before CPAP therapy was started.

The alveolar-arterial oxygen tension difference $\left(\mathrm{A}-\mathrm{aD}_{\mathrm{O}_{2}}{ }^{(1.0)}\right.$ in 100 per cent oxygen was greater than 300 torr while on the ventilator in all patients (see Table I). During the trial period of CPAP, no patient showed significant signs of respiratory fatigue (sweating, agitation, etc.); the $\mathrm{Pa}_{\mathrm{CO}_{2}}$ averaged 37 torr and $\mathrm{pH}$ averaged 7.51. Blood pressure and pulse rate remained stable during CPAP trial and therapy. Respiratory rate remained below 25 in all cases.

The $\mathrm{A}-\mathrm{aD}_{\mathrm{O}_{2}}$ decreased in each case after 3 to $10 \mathrm{~cm} \mathrm{H}_{2} \mathrm{O}$ of CPAP therapy within 24 hours ( see Figure 2). It should be noted that it has been shown recently 


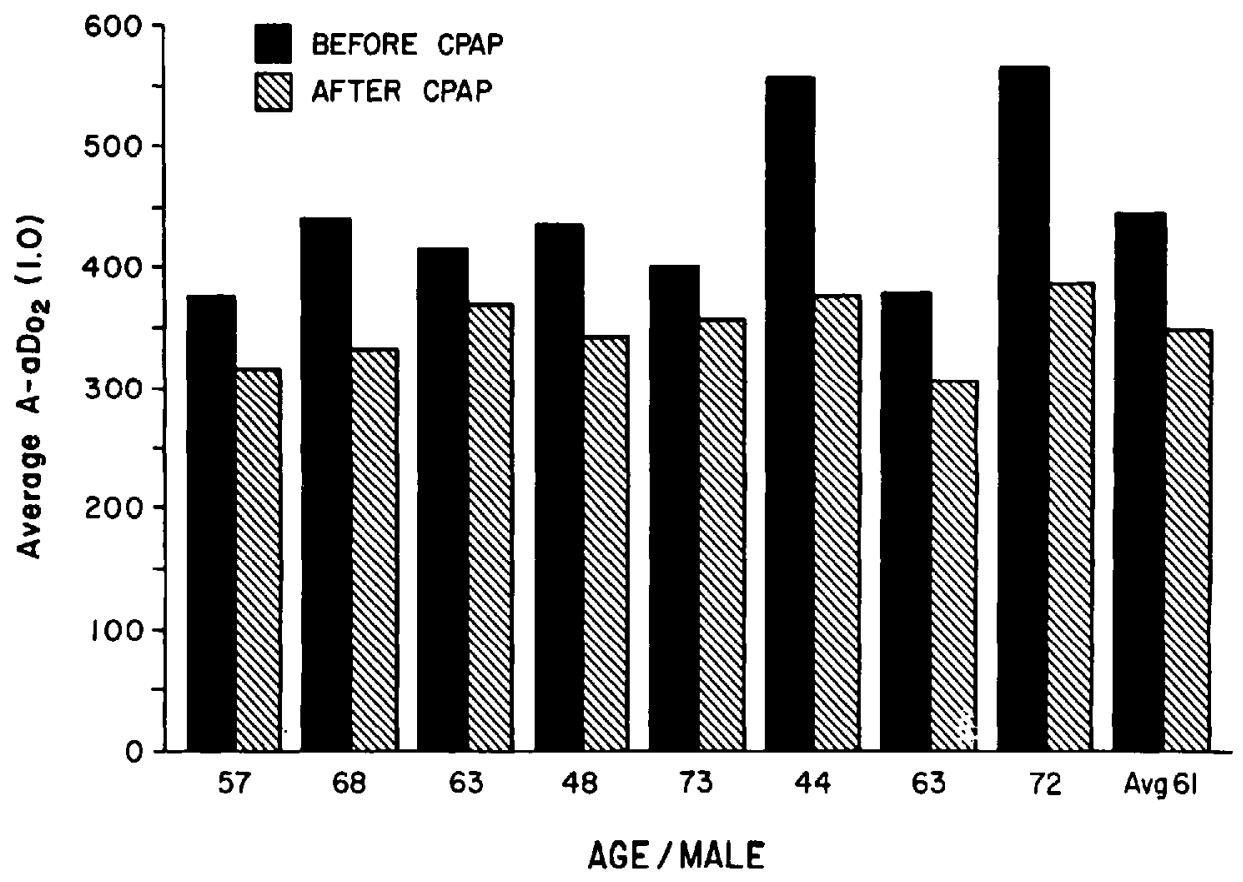

Figure 2.

by Ramchandran, et al. ${ }^{10,11}$ that 100 per cent oxygen breathing even for 15 to 20 minutes can produce a fall in FRC and an increase in intrapulmonary shunting. However, in our study there were significant improvements in $\mathrm{A}-\mathrm{aD}_{\mathrm{O}_{2}}{ }^{(1.0)}$ after CPAP therapy with the same mode of oxygen administration ( 100 per cent).

Of ten patients, only one (\#10) developed a pneumothorax after $8 \mathrm{~cm}$ of CPAP therapy for three hours. This was recognized promptly and a chest tube was inserted and connected to an underwater seal. This patient required high airway pressures (up to $45 \mathrm{~cm} \mathrm{H}_{2} \mathrm{O}$ ), while on mechanical ventilator prior to CPAP. Whether pneumothorax was a result of this or secondary to CPAP is difficult to state. No other serious complications were encountered.

Case \#1: 24-year-old white male presented with head injury, with respiratory distress secondary to aspiration of vomitus. Arterial blood gas (room air) $\mathrm{P}_{\mathrm{O}_{2}} 52$ torr, $\mathrm{P}_{\mathrm{CO}_{2}} 32$ torr, $\mathrm{pH}$ 7.37. Twenty-four hours later, a tracheostomy was done, and the following measurements were recorded: Spontaneous tidal volume (by Wright respirometer) $500 \mathrm{cc}$ inspiratory force over $40 \mathrm{~cm} \mathrm{H}, \mathrm{O}$, arterial blood gases ( $\mathrm{F}_{\mathrm{O}_{2}}$ $=1.0) \mathrm{P}_{\mathrm{O}_{2}} 211, \mathrm{P}_{\mathrm{CO}_{2}} 29, \mathrm{pH} 7.55, \mathrm{~A}-\mathrm{aD}_{\mathrm{O}_{2}} 463+, \mathrm{Vd} / \mathrm{Vt} 0.21$. The following is a summary of the subsequent course, spontaneous CPAP being instituted on day 4.

\begin{tabular}{|c|c|c|}
\hline $\begin{array}{c}\text { Day No. } \\
\# 3\end{array}$ & $\begin{array}{c}\mathrm{cm} \mathrm{H}_{2} \mathrm{O} \text { PEEP } \\
0\end{array}$ & $\begin{array}{c}\mathrm{A}-\mathrm{aD}_{\mathrm{O}_{2}}{ }^{11.01} \\
463\end{array}$ \\
\hline$\# 4$ & 5 & 328 \\
\hline \#5 & 5 & 329 \\
\hline$\# 6$ & 5 & 330 \\
\hline \#7 & 2 & 219 \\
\hline
\end{tabular}


Case \#2: 26-year-old white male with cervical spine fracture. Arterial blood gases (room air) were: $\mathrm{P}_{\mathrm{O}_{2}} 58$ torr, $\mathrm{P}_{\mathrm{CO}_{2}} 31$ torr, $\mathrm{pH} 7.50$, inspiratory force 16-18 $\mathrm{cm} \mathrm{H}_{2} \mathrm{O}$, tidal volume (T.V.) (spont.) 200-225, and while on $\mathrm{FI}_{\mathrm{O}_{2}}{ }^{(1.0)}$, the $\mathrm{A}-\mathrm{aD}_{\mathrm{O}_{2}}$ was 356 torr. The patient was mechanically ventilated and 24 hours later the vital capacity was $1100 \mathrm{cc}, T . V .450 \mathrm{cc}$, inspiratory force $35 \mathrm{~cm} \mathrm{H}_{2} \mathrm{O}$, and $\mathrm{A}-\mathrm{aD}_{\mathrm{O}_{2}}$ was 340 torr. Spontaneous CPAP of $5 \mathrm{~cm}$, was started and $24 \mathrm{hrs}$ later the $\mathrm{A}-\mathrm{aD}_{\mathrm{O} .2}$ was 249 . Discontinuation of spontaneous CPAP and extubation rapidly followed.

\section{GUIDELINES USED For CPAP THERAPY}

1. Arterial hypoxaemia not improving with dangerously high $\mathrm{F}_{\mathrm{I}_{2}}$ (greater than 0.6 ) required to maintain an arterial $\mathrm{P}_{\mathrm{O}_{2}}$ of at least 70 torr.

2. Persistence of $\mathrm{A}-\mathrm{aD}_{\mathrm{O}_{2}}{ }^{(1.0)}$ greater than 250 torr while on a ventilator despite high airway pressures and tidal volumes approaching $15 \mathrm{cc} / \mathrm{kg}$, or more.

3. Conscious and alert patients uncomfortable on the respirator and requiring repeated sedation in order to prevent fighting; this is seen frequently with high tidal volumes ( 12 to $15 \mathrm{ml} \mathrm{kg}$ ) and with high airway pressures.

4. More common causes of intrapulmonary shunting, such as water retention, pneumothorax and low cardiac output, must be ruled out or treated.

5. Persistence of respiratory alkalosis while on the ventilator because of the high tidal volumes sometimes needed (see \#2 above), which may require additional rebreathing dead space.

\section{Objective Chiteria for CPAP Therapy}

If the patient's situation meets one or more of the criteria listed above, spontaneous CPAP should be instituted. For the patient to tolerate CPAP therapy, the following conditions must be met:

1. Vital capacity of 10 to $15 \mathrm{cc} / \mathrm{kg}$ or greater.

2. Tidal volume measured during spontaneous breathing of 5 to $6 \mathrm{cc} / \mathrm{kg}$.

3. Inspiratory force of $20 \mathrm{~cm} \mathrm{H}_{2} \mathrm{O}$ or greater.

4. Arterial $\mathrm{P}_{\mathrm{CO}_{2}}$ after 20 to 30 minutes of CPAP trial not greater than 50 to 55 torr.

\section{Discussion}

There is definite evidence that any form of residual positive pressure at the end of the expiratory phase of respiration increases the functional residual capacity (FRC) and hence the lung volume. ${ }^{1,5,12,13,14}$

Continuous positive airway pressure (CPAP) prevents alveolar collapse by keeping the airways open at end-expiration. The result of CPAP is a rise in arterial $\mathrm{PO}_{2}$ and a fall in pulmonary shunting, the rise in $\mathrm{Pa}_{\mathrm{O}_{2}}$ being directly proportional to the reduction in the amount shunt, which is in turn inversely proportional to the FRC. ${ }^{15,16}$ The greater the amount of shunting across the lung, the more marked will be the effectiveness of PEEP therapy, so long as the shunt is due primarily to alveolar collapse rather than to diffusion block (alveolar-capillary block) seen in diffuse interstitial processes. ${ }^{17}$ 
In patients on ventilators a higher tidal volume is needed ( 12 to $15 \mathrm{cc} / \mathrm{kg}^{18}$ ) to decrease shunting and to improve arterial hypoxaemia. Higher airway pressures are needed to maintain such a high tidal volume on a volume respirator. Under these circumstances, agitation and "fighting" the respirator are often seen, especially in conscious and alert patients. Alveolar hyperventilation with arterial carbon dioxide tensions in the low twenties and alkaline $\mathrm{pH}$ are also often seen, unless adequate dead space is added to the system.

Under the circumstances mentioned, spontaneous breathing with CPAP can correct the hypoxaemia by reducing the intrapulmonic shunt without the need for mechanical assistance to ventilation, provided the patient meets the previously described criteria. Once CPAP is begun, careful observation of the patient is mandatory to detect early signs of ventilatory fatigue (increase in the respiratory rate, agitation, sweating, tachycardia and $\mathrm{PaCO}_{2}$ greater than 50 torr).

If the patient tolerance is good after a trial period of 15 to 30 minutes, the patient then can usually be continued on CPAP therapy alone.

Mechanical assistance to ventilation has hazards: mechanical dysfunction, more difficult nursing care, patient agitation and discomfort due to high airway pressure. In selected patients on mechanical ventilation with high intrapulmonic shunting ( $\mathrm{A}-\mathrm{aD}_{\mathrm{O}_{2}}$ greater than 300 torr) with adequate ability for spontaneous respirations, CPAP therapy may allow discontinuation of the mechanical ventilator. In conscious and alert patients, tolerance to CPAP is frequently better than that of mechanical assistance to respiration. As shown in the illustration, CPAP therapy is a relatively simple device with low cost.

\section{SUMMARY}

A discussion of the indications for and technique and effects of spontaneous CPAP are presented, showing its value in the treatment of hypoxaemia, using a basically simple system. A series of patients are presented showing a typical clinical course.

\section{RÉSUMÉ}

Les indications, la technique et les effets de la ventilation spontanée en Pression Positive Permanente (CPAP) discutés dans ce travail démontrent la valeur de cette technique en présence d'hypoxémie.

Les auteurs décrivent une méthode simple pour réaliser ce type de ventilation et ils illustrent leur travail par la présentation de quelques cas cliniques pertinents.

\section{REFERENCES}

1. Kumar, A., Falke, K.J., Geffin, B., Aldredge, C.F., Laver, M.B., Lowenstein, E., \& Pontoppidan, H.B. Continuous positive-pressure ventilation in acute respiratory failure. NEJM 283: 26: 1430-1436 (1970).

2. LUtch, J.S. \& MUrray, J.F. Continuous positive-pressure ventilation: Effects on systemic oxygen transport and tissue oxygen transport and tissue oxygenation. Ann. Int. Med. 76: 193-202 (1972). 
3. PetTy, T.L., Nett, L.M., \& Ashbaugh, D. Improvement in oxygenation in the adult respiratory distress syndrome by positive end-expiratory pressure. Resp. Care 16: 4: 173-176 (1971).

4. Down, J.B., Klein, E.F., \& Monell, J.H. The effect of incremental PEEP on $\mathrm{Pa}_{\mathrm{O}_{2}}$ in patients with respiratory failure. Anesth. \& Analg. 52: 2: 210-215 (1973).

5. Ashbaugh, D.G., Petry, T.L., Bigelow, D.B., \& Harris, T.M. Continuous positivepressure breathing in adult respiratory distress syndrome. J. Thor. Cardiovasc. Surg. 57: 1: 31-41 (1969).

6. Gregory, G.A., Kitternan, J.A., Phibes, R.H., Tooley, W.H., \& Hamilton, W.K. Treatment of the idiopathic respiratory distress syndrome with continuous positive airway pressure. NEJM 284: 24: 1333-1340 (1971).

7. Civetra, J.M., Brons, R., \& Gabel, J.C. A simple and effective method of employing spontaneous positive pressure ventilation. J. Thor. Cardiovasc. Surg. 63: 2: 312-317 (1972).

8. Pontoppidan, H.B., Gefrin, B., \& Lowenstein, E. Acute respiratory failure in the adult (three parts). NEJM 287: 609-698, 734-752, 799-806 (Oct. 5, 12 \& 19, 1972).

9. Pontoppidan, H.B., Geffin, B., \& Lowenstein, E. Acute respiratory failure in the adult. Little, Brown \& Company, Boston (1973).

10. Ramchandran, P.R. \& FaIrLey, H.B. Changes in functional residual capacity during respiratory failure. Canad. Anaesth. Soc. J. 17 (July 1970).

11. Markello, R., Winter, P.M., Olszowka, A, et al. Assessment of ventilation inequalities by arterial-alveolar nitrogen differences in intensive care patients. Anesthesiology. 37: 4-15, 1972.

12. Falke, K.J., Pontcppidan, H.B., Kumar, A, et al. Ventilation with end expiratory pressure in acute lung disease. J. Clin. Invest. 51: 2315-2323 (1972).

13. Barach, A.L., Martin, J., \& Eckman, M. Positive pressure respiration and its application to the treatment of acute pulmonary edema. Ann. of Int. Med. 12: 754 (1938).

14. McIntyee, R.W., Laws, A.K., \& Ramchandran, P.R. Positive expiratory pressure plateau: improved gas exchange during mechanical ventilation. Canad. Anaesth. Soc. J. 16: $6: 477-486$ (1969).

15. AsmbaUGH, D.G. Effects of ventilatory methods and patterns on physiologic shunt. Surgery 68: 99 (1970).

16. Finley, T.N., Lefant, C., Hash, P., Piper, J., \& Rahn, H. Venous admixture in pulmonary circulation of anesthetized dogs. J. Applied Physiol. 15: 418 (1960).

17. Ashbaugh, D.G. \& PeTty, T.L. Positive end expiratory pressure: physiology indications and contraindications. J. Thor. Cardiovasc. Surg. 65: 1: 165-170 (1973).

18. Hedley-Whyte, J., Pontoppidan, H.B., Laver, M., et al. Arterial oxygenation during hypothermia. Anesth. 26: 595-602 (1965). 